\title{
Strategic Value of Agricultural Business Networks in Sustaining Common Goods
}

\author{
Ludovico Bullini Orlandi ${ }^{1, *(D)}$, Elena De Martino ${ }^{2}$, Cecilia Rossignoli ${ }^{3}\left(\mathbb{D}\right.$ and Sabrina Bonomi ${ }^{4}$ (i) \\ 1 Department of Business Administration, University of Verona, 37129 Verona, Italy \\ 2 Ferroli S.p.A. 37047 Verona, Italy; elenadiemme@gmail.com \\ 3 Department of Business Administration, University of Verona, 37129 Verona, Italy; cecilia.rossignoli@univr.it \\ 4 Faculty of Law, E-Campus University, 22060 Novedrate, Italy; sabrina.bonomi@uniecampus.it \\ * Correspondence: ludovico.bulliniorlandi@univr.it
}

Received: 24 September 2019; Accepted: 24 October 2019; Published: 28 October 2019

check for updates

\begin{abstract}
This article aims to highlight the positive relationship between the organizational form of the agricultural business network and common goods, thus seizing their strategic value for the company in terms of protection, development, and sustainable use. The common goods analyzed in this research are of different origins: natural, such as the local environment and biodiversity, and artificial, such as cooperation and communication. To this end, a four-year longitudinal study was conducted to study the relationship between agricultural business networks and common goods. This study provides an in-depth analysis of the literature, which highlights the following as main themes: the sharing of values, the importance of trust and reputation, the central role of adaptive management, learning as participation, and environmental sustainability. The chosen case highlights how agricultural business networks can be considered both an effective tool in the protection and sustainable use of common goods and a tool that allows the development of the commons. Both these aspects have a strategic value for an organization that can derive significant benefits both from common goods developed and from the implemented organizational form and simultaneously protect the environment with strong positive externalities for itself and the community.
\end{abstract}

Keywords: common goods; business network; inter-organizational processes; network organizations; sustainability; adaptive management; learning as participation

\section{Introduction}

The network contract in agriculture was implemented for the first time in 2014, thanks to the Italian Decree Law 91/2014 (converted into Law 116/2014). This decree introduced an innovative form of network contract involving collaboration among small- and medium-sized agricultural enterprises with the aim of exploiting their potential reciprocal relationships. A main feature of this form of collaboration is the potential for participating companies to receive a quota, which is established in the contract, of the overall production obtained on the basis of the original right title. According to the legislation, the original right title means that the property right that a subject obtains on an object or an asset is independent of the right of any other previous owner. Therefore, the value of production can be divided among the contracting organizations according to the quota established in the contract, and the product obtained in the land of other companies inside the network can be viewed as if it were obtained from one's own land. This issue has significant implications in terms of tax benefits.

Given the presence of these benefits, the network contract in agriculture must comply with some specific clauses: 
- It must be formed by small and medium-sized enterprises of every legal form, individual or collective, with fewer than 250 employees, and an annual turnover of fewer than 50 million euros or total assets less than 43 million euros as listed in financial statements [1];

- Agricultural businesses must share production factors, such as human resources, knowledge, skills, and equipment;

- The general objectives of innovation and improvement of the competitive capacity of each individual participant must be specified, and moreover, the methods to calculate the progress toward the goals established must also be specified;

- The contract must indicate the rights and obligations of the companies involved in the network and the percentages of redistribution of the product;

- All participants must conduct agricultural activities, and activities must be the same across all enterprises in a network (e.g., wine or fruit production).

At the end of 2018, the number of companies with a business network contract in Italy had increased by $34 \%$ compared with the previous year to 31,405 , of which $18.5 \%$ (6347 companies) took part in agricultural business networks [2]. Currently, business networks are becoming fertile ground for the development of opportunities, behaviors, and changes that favor, encourage, and protect the commons [3]. Common goods and resources, or more briefly the commons, can be classified neither as a private good (because it is not possible to exclude anyone from their use) nor as a public good, since if this were the case, since a subject consumes the good, this would not affect the use by other parties. Thus, the commons, although not falling into these two categories of goods, do not share specific characteristics; they are goods with a high degree of deductibility, and it is difficult to be excluded. Common resources are assets that are exploited by more than one user, and hence, exclusion mechanisms are costly and difficult to apply. These can be divided into natural and artificial: natural resources are found in nature (e.g., air, water, biodiversity, animals, and plants), and artificial resources are produced with human labor and technology (e.g., irrigation systems, weather stations, roads, channels, and the internet).

Common natural resources can be categorized as renewables and nonrenewables. The former can be regenerated through spontaneous processes, whereas the latter are destined to run out because their use necessitates their depletion. Common artificial resources can be classified as material and intangibles. The former includes a set of concrete resources with different natures (e.g., mechanical, chemical, and electronic), whereas the latter lack concreteness (e.g., the digital world, including the internet and databases, corporate knowledge, innovation, and cooperation) [3]. These last ones fall into a new category: the so-called "new commons" [4]. This label indicates a much wider group of eco-socio-technical systems that provide common resources that are mainly created through social and learning processes, such as local traditions, the reputation of a district, or Wikipedia [5].

Although these issues are relevant, very little is known about the role of agricultural business networks in preserving and developing commons. Further, in the literature, no studies consider the Italian context; this is of significant interest since most of the companies present in Italy are small and medium sized. To address this lack of research, this article focuses on the following research question: What role does the organizational network play in the implementation, development, and protection of the commons in the agriculture industry?

To address this question, this work is structured as follows. Section 2 introduces a theoretical framework to interpret the research question. In Section 3, we present the research methodology. In Section 4, we present a longitudinal exploratory study conducted on an extensive network of agricultural enterprises in the Valpolicella (near Verona city). In Section 5, we discuss the findings, and in Section 6, we present the conclusion. The chosen case highlights how agricultural business networks can be considered both a useful tool in the protection and sustainable use of common goods, such as the local environment, and a tool that allows the development of commons, such as collaboration, communication, and sharing of knowledge, skills, and instrumentation. All these aspects have strategic value for organizations that can benefit greatly both from the common goods developed and from the 
implemented organizational form, and at the same time protect the environment, with strong positive externalities for themselves and the community.

\section{Theoretical Background}

\subsection{Cooperative and Noncooperative Approach: Importance of Trust and Friendly Relationships}

The optimal management of common goods takes into consideration two distinct approaches: cooperative and noncooperative. Regarding the noncooperative approach, the results of the optimization model indicate that, because of an over-use of the commons, users can obtain short-term benefits. However, this leads to adverse effects on the asset itself in the long term, and its destruction may occur. From the analysis carried out at the beginning of the utilization period, users obtain greater benefits by adopting the noncooperative approach; however, after 25 years, this is exceeded by the cooperative approach. Expenses in the noncooperative approach increase over the years and, consequently, the advantage that can be obtained in this type of management decreases. Finally, this approach becomes disadvantageous to the user. In conclusion, it can be said that the users' benefits are higher in the short term in a noncooperative approach than in a cooperative approach, but these benefits diminish in the long term because of the exploitation of the resource [6].

Trust is crucial for collective action since cooperative behavior must take into account the risk that others do not cooperate, which means that the cooperators do not receive any benefit and bear all the costs related to the cooperation. Trust is an essential determinant of sustainability because it influences the strategic interaction between actors whose individual incentives are not necessarily in line with those of the community [7]. Therefore, to predict that an actor will behave cooperatively, a certain degree of reciprocal trust in cooperative action, or "trust in action," must be assumed [8].

Another type of trust is "trust in information," which involves trusting the information provided by other actors. This type of trust has as its object information of various kinds-scientific, academic, and political - that are the basis of the decision-making process. This leads us to consider how belief systems can influence confidence in information and, by proxy, can also influence confidence in actions. Both forms of trust are fundamental for the management of common goods and for organizations in the network; belief in information can lead to trust in the completeness and depth of the data provided by other actors, and confidence in actions can lead to trust in the actions and behaviors of other actors [8].

In thinking about the processes that generate trust within a network, it is useful to introduce the concept of a trusted network or a network in which individual actors can be connected by dyadic relationships of trust [9]. Within a network, reputation, homophily, and transitivity have a positive effect on trust. Reputation has an effect in terms of reciprocity; that is, if one network actor trusts another, it is likely that this trust is returned (or "returned") later by another actor in the network $[10,11]$. Transitivity is a phenomenon commonly known as "the friend of my friend is my friend," and in this case, it implies that, if a particular actor is trustworthy, those actors he or she trusts can be considered reliable [8]. Finally, homophily is the tendency of network actors to forge links with others who are similar to them [12]. It can be introduced in the context of networks to highlight the tendency on the part of individuals to believe that the similarity in some easily observable attributes is an indication of similarity in terms of other characteristics, more challenging to observe, that are fundamental for the formation of a trust relationship. Easily visible attributes include educational background and political or institutional preferences.

Several studies consider trust the fundamental factor in the success of the network because it contributes to the minimization of opportunism between parties and, consequently, to a reduction in transaction costs [13-15]. Trust represents a preliminary and necessary ingredient to start the relationship between the actors who then, through "friendly" relations, are encouraged to cooperate. A crucial figure in spreading trust within the network is the social entrepreneur. 


\subsection{The Social Entrepreneur}

Social entrepreneurship develops opportunities and innovative solutions aimed at (re)generating the common good. This emerging organizational form poses unprecedented challenges to group decision-making and negotiation studies. Two key factors can be identified that make social entrepreneurship a particularly stimulating and exciting context for the decision-making process and the related sensemaking and negotiation processes. First, in social entrepreneurship, at least one common good is at stake. Second, social entrepreneurship typically develops systems of distributed activities, which must catalyze cooperation according to conflicting institutional logic.

When a common good is at stake, people can implement two different behaviors:

- Short-term opportunism-it determines decisions that put common goods at risk;

- Long-term cooperation-it translates into decisions that protect and develop common goods.

The literature on the commons identifies in distributed self-management the critical process for making the right decisions [16]. In addition to self-regulation based on personal relationships, in recent years at least three additional factors have been identified as key to enhancing communication within organizations and implementing decision-making [17]:

- Transparency-essential to encourage behaviors aimed at the development of common goods (the possibilities of social control provided by highly transparent systems are a powerful mechanism to discourage opportunism and stimulate cooperation);

- Nested institutions-the creation of relationships within the organization at all levels that must encourage and put into practice the sharing of information both inside and outside, that is, at the different organizational levels;

- Effective management of environmental uncertainty.

To improve communication within the organization and consequently develop effective decision-making, a social entrepreneur must successfully encourage transparency, develop nested institutions, and deal with the uncertainty inherent in managing a common good [17]. Social entrepreneurs focus on neglected activities with significant positive externalities, develop economic actions to solve problems related to common goods, and often influence governments to create legislation that legitimizes and supports their innovation. The social entrepreneur becomes a key player in the complex process of institutional transformation that is necessary to protect and develop complex common assets [18].

In supporting cooperation, and therefore the functioning of the network, network leaders play a fundamental role by managing collaboration to minimize risk of adherence for potential network members. They also engage in the generation of trust for the stakeholders and ultimately create social and intellectual capital. Social capital is the basis for the exchange of knowledge and innovative processes, which are crucial elements of intellectual capital. The role of the network manager, whether it is a formal association, an individual, an organization, or a combination of these, is key to achieving collective results [19]. To achieve the objectives of the community, previous studies have highlighted how co-adaptive management and learning as participation are of considerable importance.

\subsection{Adaptive Co-Management and Learning as Participation}

The management of fragile common environmental resources, such as fisheries, water, clean air, and land, is fundamental to improve the resilience of ecological systems. Scholars engaged in this field of study have realized that it is impossible to achieve more resilient ecological systems [20] by relying on technocratic management that translates scientific knowledge into policies such as guidelines, rules, roles, incentives, or sanctions [21]. Social actors can influence, fight, boycott, violate, ignore, or misinterpret policies, and this further increases the unpredictability of the effects of policies designed to improve the resilience of the ecological system. Therefore, in most cases, the effective governance of an environmental resource implies dynamic management, based on science and feedback from 
a socio-ecological system (SES) [22] and must necessarily be based on a collective, interdisciplinary approach and adaptive learning processes: adaptive management.

According to the adaptive management approach, the knowledge that adaptive managers can gain by studying feedback on their decisions could be even more important than the impact of the decisions themselves. Once acquired, this knowledge allows for further adjustment of choices and improvement of the adopted policies. For this reason, adaptive management implies a strongly experimental attitude of decision-makers [18].

The involvement of the local community and the main stakeholders is indispensable for the success of adaptive management [23]. These results have recently led to a growing interest in adaptive co-management, namely, adaptive co-management based on the co-production of adaptive knowledge [24]. Therefore, the term implies an inclusive decision-making process, generating significant attention to the role of science and the broader economic, social, and institutional contexts [25]. "Adaptive co-management" systems are flexible systems based on shared management of resources, adapted to specific places and situations, and they are supported by, and work with, various organizations at different levels. The flexible structure allows for learning and prompt responses to change; conversely, rigid and centralized institutions, in the context of the protection or development of common goods, lead to poorer results [26]. Adaptive co-management can be defined as a process through which institutional arrangements and ecological knowledge are tested and reviewed in a dynamic, continuous, and self-organized learning process [27].

In the so-called adaptive view of co-management, scientists collaborate with other subjects, such as the community, to build a collective sense of how decisions affect a specific common good [24]. The vision of adaptive co-management highlights the role of a "bridge organization" [28] that facilitates the constructive interaction between the main stakeholders of the common goods, integrates knowledge, controls the common goods and their fragility, enables commitment, makes participatory decisions, imposes rules, and collectively makes sense of the consequences of decisions. In this light, the decision-making process can be considered the engine of a continuous and adaptive process as it generates changes and, therefore, new feedback and new learning possibilities [17].

Small communities have limited resources, and when power is concentrated in the hands of a few elite individuals, it is difficult for other elements within the community to obtain a share of that power. This makes it difficult for new members to engage their talents. An excellent method for solving this problem is the "Learning as Participation" approach [29], which allows fundamental changes to be made in the behavior of the members of an institution, and even the facilitation of greater cooperation, mutual trust, and the ability to face more problems. According to the Learning as Participation theory, knowledge is the result of a dynamic process in which a subject actively participates in a context in which numerous subjects interact. The participation by all individuals, and the sharing of their knowledge and skills, allows the group to gain experience and therefore to increase their knowledge; in this way, even small companies can benefit from a more considerable amount of information.

\section{Methodology}

\subsection{Research Setting}

Omega is a network of agricultural companies sharing the grape production chain through an organizational arrangement that is different from the usual customer-supplier relationship, with the specified aim of enhancing the quality and uniqueness of the Valpolicella wine products. Therefore, the Omega network aims to develop and improve the whole grape supply chain, from pruning to harvesting. Omega, as an agricultural enterprise network, creates the potential for carrying out joint activities and sharing knowledge, skills, and other networks facilities. It also makes it possible to take advantage of the work of network contractors and to obtain better contractual conditions with suppliers in exchange for grapes with an original title, repaid at a competitive price, about $10 \%$ more than the market price. 
The decision by the network leader to use this organizational structure is linked, as the manager of Omega explains, to the fact that "in a path of continuous innovation the company has acquired the awareness of the environment." In fact, in its progression toward a high-quality product, it introduces the elimination of herbicides and the respect of the wine heritage and the local environment in which it is inserted as a cornerstone. Omega, like most agricultural business networks, is a contracted network, and therefore without legal and fiscal subjectivity. The network today consists of a leading company and 25 companies of various sizes, most of which are distributed in the Valpolicella area, with a minority in Bolgheri in Tuscany.

The companies were chosen on the basis of production standards, namely the quality of the raw material supplied, the sharing of values and objectives concerning the environment, and the processing of grapes. Within the network there is a manager, an employee of the lead company, who acts as a link between the lead company and the network. The manager deals with facilitating communication regarding directives, and training of the companies participating in the network through specialized courses. The manager also holds the meetings and prepares the network cultivation plan or business plan, which is then approved by a certified accountant outside the network.

The planned duration of the network contract is six years, with the possibility of extension. The network's mission is to achieve quality production, respecting the environment and the workers, and enhancing the wine heritage. To this end, Omega implements a series of best practices: herbicides and insecticides are not employed; new sustainable practices are experimented with; employees undergo periodical medical examinations to check their physical suitability to job tasks; waste production is minimized by using high-quality materials; great attention is paid to the environment, with uncultivated areas of land left untouched, insect houses constructed to safeguard biodiversity, and natural materials chosen.

Omega is significantly committed to socially and environmentally responsible innovation. It has official certifications concerning the quality, health, safety, and protection of the environment from Biodiversity Friends and Equalitas. In conclusion, the Omega case can be considered an appropriate research approach to address the research question of this study, since the phenomena of interest occur with particular intensity in this context.

\subsection{A Longitudinal Case Study}

In a recent commentary by the editors of the Academy of Management Journal, Eisenhardt et al. [30] strongly encouraged inductive approaches, based on in-depth case studies, to develop novel theories that contribute to addressing societal challenges. In this light, the contribution of these inductive studies lies in the development of new concepts, models, or frameworks. Inductive studies cannot be replicable, per se, but they are expected to innovate the field by triggering new streams of reproducible studies dedicated to the testing of the latest models and frameworks provided. Following this authoritative suggestion, we leverage an in-depth longitudinal case study based on participant observation, document collection, and interviews to answer the research question.

In the social sciences, case study approaches allow scholars to grasp the complexity of a single case in a context [31]. This case, based on different sources of qualitative data (see Table 1), could provide an exploratory point of view on a recent phenomenon [32] and, as a longitudinal study, contribute to the development of best practice, sustainable use, and development of the commons. The data were collected through participant observations by one of the authors [33] from 2015 to 2019. In 2015, the leading company of the chosen agricultural business network participated in a focus group, held by one of the authors, to start a journey aimed at building a sustainable business network. The participant observation process provided first-hand data that were valuable and difficult to replace. 
Table 1. Data collection.

\begin{tabular}{ccc}
\hline Collected Data & Number & Note \\
\hline Focus Group & 1 & $\begin{array}{c}\text { At the beginning of the research, Omega's leader took part in a } \\
\text { focus group organized by one of the authors. That focus group } \\
\text { dealt with the business network organization form. }\end{array}$ \\
\hline Interviews & 23 & $\begin{array}{c}\text { The interviews comprised } 5 \text { informal interviews, collected } \\
\text { during a visit to the firm's headquarters to discuss the } \\
\text { business network and commons, and 18 in-depth structured } \\
\text { interviews, digitally recorded and then transcribed. }\end{array}$ \\
\hline $\begin{array}{c}\text { Direct Observation } \\
\text { Notes from the Direct } \\
\text { Observation }\end{array}$ & 95 pages & $\begin{array}{c}\text { The authors visited the firm's headquarters } 6 \text { times, the } \\
\text { vineyard once, the structure where the drying takes place once. } \\
\text { The responsible of the business network came to the authors' } \\
\text { office once. }\end{array}$ \\
\hline $\begin{array}{l}\text { Internal Document } \\
\text { Related to Omega }\end{array}$ & 5 & $\begin{array}{c}\text { Several notes were taken during the direct observation at the } \\
\text { different organizational units. }\end{array}$ \\
\hline $\begin{array}{l}\text { Data Collected Online } \\
\text { Data from Press }\end{array}$ & 3 & $\begin{array}{c}\text { During direct observations, there was a chance to observe } \\
\text { several documents concerning the network's activity. }\end{array}$ \\
\hline
\end{tabular}

The participating observer was involved in official network meetings and training courses and regularly collected critical data over time, thus allowing for longitudinal development of the case. These critical data included interviews, direct observations, notes, internal documents related to the agricultural business network (labeled in this study as Omega), data collected online, and data from the media, as can be seen in Table 1.

The analytical process employed in the case study consists of three steps (see Figure 1). The first step consists of qualitative structured interviews about the development of business networks and the strategic value of the commons. These interviews were submitted to the network manager and 15 other companies selected according to their time spent in the network. Some companies joined Omega at the beginning, others one year before, and others just a few months before the interview; this choice was made to account for different perceptions of actors based on the length of their time in the network. The interview was composed of three parts. The first part comprised questions of a general nature aimed at framing the interviewed company and the network to which it belonged-for example, name, sector, turnover, and number of employees. The second part consisted of a series of 17 open questions aimed at analyzing the strategic value of common goods in the context of business networks. The third part consisted of multiple-choice questions exploring the influence of the network on the performance of the company itself. For this purpose, sales, market shares, and return on investments were examined. The average duration of the interviews was 45 minutes.

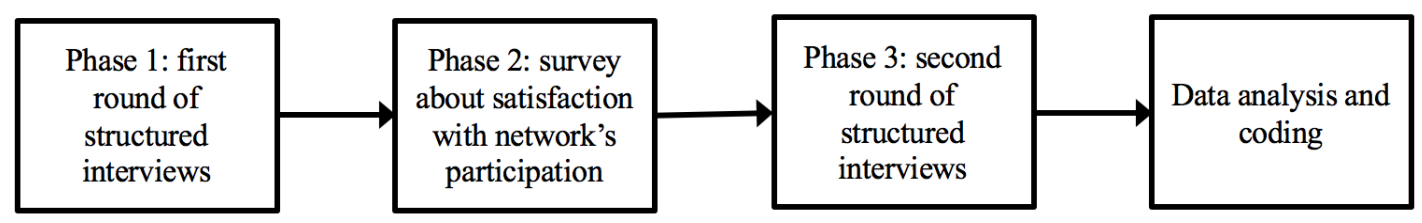

Figure 1. Analytical phases.

The second step involved the analysis of satisfaction using a Likert-type scale, which allowed assessment of the satisfaction of individuals concerning their participation in the network. In this part, interviewees were asked to evaluate, on a scale from one to five, their levels of satisfaction with 
participating in the network. For research purposes, this step enabled the analysis of individual participants' subjective satisfaction, allowing us to compare the perceptions of all the network operators, and to calculate an average of the evaluations.

Finally, the third step was the submission and analysis of a qualitative interview on the topics highlighted in the literature. It consisted of 10 questions and was submitted to the leader and the person in charge of the network, to grasp the congruencies and discrepancies between the theory and reality. The average duration of the interview was 60 minutes. These questions were structured based on the results of the theoretical framework presented above.

The coding phase was carried out in three steps, according to methods prescribed by Miles, Huberman, and Saldaña [34]. First, open coding was conducted to identify the main issues and the general contents in the analyzed data. Then, axial coding refined the open coding by identifying the relevant categories and the connections between them. Finally, selective coding was conducted to identify the fundamental aspects concerning the commons and network relationships highlighted by the literature. A table summarizing the codes identified for the analysis of the case is available in Appendix A.

\section{The Strategic Value of Commons in Omega: A Network Supporting Sustainability}

\subsection{Cooperative Approach: Development of Trust}

Omega adopts a cooperative approach in its management, aimed at creating a workgroup that shares the same values and is oriented toward the same goal of sustainability. To this end, the development of trust is very important. Omega encourages network participants to share their knowledge and experience by encouraging the "trust in information" - trust in the beliefs offered by other parties. Knowledge within the network can come from both the leader and all the participants, who have the same importance regardless of the size of their land. In fact, the network leader encourages the network to collaborate: "If you have something to share—experiences and knowledge—bring them; we are not the best. We try to document and improve ourselves and there can always be someone smarter, better documented than us who can bring culture into the network, and all this can also come from the small farmer who put one hectare on the network, not only from the big one."

Trust is built up within the network by people working side by side each day; it arises from the direct relationships between the people that constitute the network. The network manager highlights this aspect as follows: "To build a relationship based on trust, during the whole winter I personally meet people of other network companies, and I share my specialization, during this long period in which we work together we create a strong bond, we create trust."

In addition to trust in the network participants, trust in the network leader is central; these are the people in charge of providing directives to all network members. These directives are not obligations but advice that, if followed, lead to the achievement of the final objective. Although they may not represent the only correct way to operate, they are nonetheless the result of the experience of specialists in the sector. To this end, even the good reputation of the network leader is of considerable importance since it represents an advantage in the network expansion phase. The company leader of one of the participating firms, Gamma, noted, "Given the quality, history, experience, and knowledge of the leader company of the network, all the participants are pleased to join the network; it would be expensive to do all the studies that they have already done," highlighting how a positive reputation encourages participation in the network.

Positive experiences contribute to the formation of a relationship of trust that may flourish in the medium to long term; in fact, the member of the network can choose to join it with a small land plot and increase the contributions in the following years in relation to the results obtained. Moreover, within the network, mutual reputation arises; in fact, from the moment in which a subject chooses to trust another member, that trust will be reciprocated. The company leader of Beta stated, "The other network operators are noncompeting collaborators; very often we exchanged machinery, which 
without the network would not have been possible because I would not have known them, and I would not have created the confidence that there is." All these aspects have enhanced the relationship of trust based on the mutual reputation that allows implementing cooperative behaviors in the network.

Given the tendency to trust one's peers, in the construction of workgroup Omega gives priority to the similarity of companies, sharing of objectives, and geographical proximity. This approach can be traced back to homophily, which makes it possible to facilitate communication and cooperation, as the network leader states, "We are all farmers, therefore sharing the objective is essential, and geographical proximity allows interventions on the territory to work side by side and therefore to transfer knowledge."

\subsection{Adaptive Co-Management and Learning as Participation in Omega Network}

Within the network there is a strong orientation toward sharing of knowledge and skills that stimulate learning; the leader adopts an attitude of willingness to listen. In fact, he says, "We do the plan, but we are open to the ideas from the network because thanks to listening we are able to innovate [...] there can always be someone smarter, better documented than us who can bring culture into the network, and all this can also come from the small farmer who put one hectare on the network, not only from the big one."

This statement highlights how the network leader can act as a social entrepreneur who considers not only economic interests but also social interests, who listens to his or her collaborators, and who is focused on innovation and continuous improvement. The network leader does not presume to be the best but rather encourages members of the network to share experiences and knowledge to perfect the work of the network and reach the goal of excellent certified and sustainable quality.

The management of Omega is open to novel ideas that "are experimented and tested in the field to defend the vine and replace old-generation products with the most innovative ones and reduce their number; that's why we dedicate a few hectares to experimentation." The network manager shows great attention to the development of best practice and the promotion of sustainability. Management can, therefore, be defined as co-adaptive, since knowledge within Omega, coming from both experiments and knowledge sharing, allows the modification of practices to define best practice.

The leader of the lead company places great importance on training network members, organizing practical and theoretical courses on a broad range of topics from safety at work to pruning and two-way communication, encouraging those who participate in the network to share their experiences and knowledge. Further, the experience and knowledge of the leader, the result of 40 years of study and work, are made available to the network and make it possible to improve the quality of both the work performed and the products. This is recognized by the individual network operators who are stimulated to be part of this reality; this can be seen in the words of the head of Gamma firm: "Given the quality, the historicity, the experience and the knowledge that they like to enter the network, it would be expensive to do all the studies they have already done."

Working side by side, the network's workers build relationships based on trust that allow them to learn together and develop best practices. These relationships facilitate dialogue between participants and allow them to share doubts and concerns, through which reciprocal learning arises. Moreover, the organization of technical courses presented by expert technicians allows for the concrete testing of working techniques, and thus enables learning through active participation.

The Omega leader has appointed as experts some employees of its own firm. This firm acts as bridge organization, facilitating communication between the network's participants and the leader, and improving interaction via both top-down and bottom-up communication channels. For example, the owner of Gamma points out that, "I am always in contact with the two technicians, but the good thing is that the network leader is also available, and I feel in a position to contact him without problems." This quotation highlights that it is possible to have transparent and direct communication in the network; it does not have too many hierarchical levels facilitating interactions. 


\subsection{Omega: A Network Supporting Sustainability}

The Omega leader can be seen as a social entrepreneur because he develops opportunities and innovative solutions aimed at (re)generating the common good by stimulating cooperation. For example, he organizes training courses on pruning that have a positive effect on the commons, increasing the longevity of the plant (common natural renewable), and working side by side builds trust through encouraging cooperation (common artificial immaterial). Because of research and development activities, the network replaces some chemical products with natural processes, with positive effects on the reference environment (renewable natural common).

Social entrepreneurship creates positive externalities, and this occurs in Omega, where considerable attention to the environment brings benefits to the community in the long term and facilitates progress toward the development of cooperation, experimentation, and training. All this creates benefits for network members and product quality with a view to sustainability. "We try to do our utmost to have a double benefit from the actions we put in place: of social sustainability and economic sustainability," says the Omega leader. This view is confirmed by the entrepreneur of Gamma who recognizes the importance of the orientation of the leader and the network for collective well-being: "We are looking for something new that can be useful in a broad sense, for collective well-being and not just for economic well-being."

Omega's objectives are expressed mainly in terms of higher quality, and not quantity, and to obtain products in line with these aims, as the Alfa entrepreneur states, it is essential to respect the environment and the territory. He declares, "if I want to get a quality product, being a fruit of the earth, the importance of respecting the land and the environment cannot be left in the background."

The network offers a product that respects, protects, and safeguards the environment. In so doing, "it has a vision toward the future, drawing the world of viticulture, introducing innovation, and new topics such as sustainability, the attention of the territory, of the landscape" (Gamma entrepreneur). One of the most important aspects is that Omega's choice of sustainability is not only an answer to a market expectation; as the Gamma entrepreneur states, "It is not produced this way only because the market requires it or because doing so we can earn more, or because everyone does it, but because it is heard from within, because for ethical and ecological reasons we feel it is right."

The network's participants share these objectives, and decisions are consistently made with these corporate values that are not influenced by the volatility of the external environment. The leading company, Omega, cares about environmental sustainability. That is why, since the year of the foundation of the network (2016), it has implemented correct agricultural practices with respect to biodiversity and shared them with other participants of directives.

Biodiversity is crucial for the provision of natural resources used by humans, such as water and energy resources. The first certification obtained by the network was from Biodiversity Friends, a reference standard for agricultural companies, headed by an ONLUS World Biodiversity Association (WBA), and is based at the Civic Museum of Natural History in Verona. This certification represents a stimulus for organizations to support an increase in biological diversity, which corresponds to improvements in the nutritional value and quality of their products. In the Biodiversity Friends network project, it is vital: "The certification is at the base of the network project, and consequently, all network operators must strive to satisfy the quality indicators. The certification then falls on the product, the wine, and since this is the fruit of the grapes, all must respect the same standard to obtain the certification" (Omega network leader).

In mid-2018 the network obtained another certification, "Equalitas." It certifies the sustainability of the entire wine supply chain, and organizations, products, and territories can be certified. Equalitas is a stakeholders' movement that aims to aggregate companies in the wine sector for a homogeneous and shared vision of sustainability. The approach that is applied to sustainability is represented by three pillars: environment, society, and economy. With the introduction of Equalitas, the network declares with great transparency its interest in sustainability—environmental, social, and economic - while promoting effective and efficient communication within the network. 


\section{Discussion}

The Omega agricultural network develops, safeguards, and exploits common resources with strong positive externalities for itself and its community of reference. In analyzing the case studies, we developed a data structure (Figure 2) that visualizes how different levels of coding are connected during data analysis (Appendix A). At the end of the analytical processes, four selective codes were identified, such as the fundamental aspects concerning the commons and network relationship highlighted by the literature. These selective codes emerged through the analysis of 12 axial codes connecting all the open codes that represent the general content of the statements of the subjects interviewed during the research (in the proposed example, 18 open codes are provided as an example).

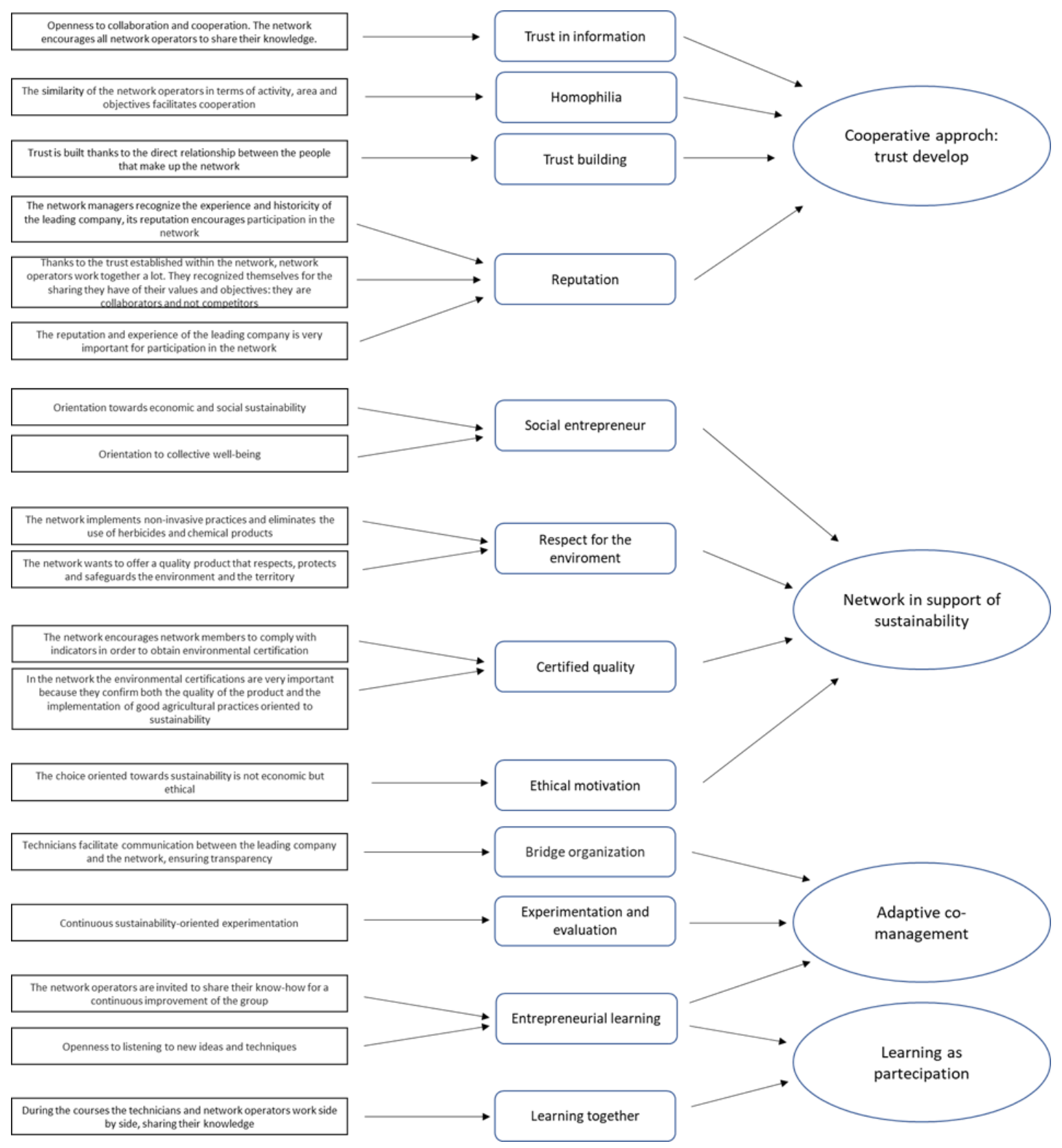

Figure 2. Data structure. 
The first selective code is the cooperative approach and the development of trust. Trust represents a preliminary and necessary ingredient to start the relationship between the subjects who then, through "friendly" relations, are encouraged to cooperate [9]. The cooperative approach turns out to be, for literature, an aspect of significant importance to developing the common assets within a business network. Cooperation is made possible by the trust established within the network, manifesting in the trust information. Network participants are, in fact, encouraged to share their experiences and knowledge [8]. Omega confirms the need to create a workgroup made up of "homogeneous" people; by supporting homophily in the choice of participants, individuals who perform similar activities and have the same goals are selected, and this facilitates cooperation [12]. In Omega, building trust, a process assisted by direct human relationships, plays an essential role in supporting cooperation. Trust is built by facilitating communication between participants, encouraging collaboration, and sharing knowledge and experience, thus establishing positive relationships [7]. The last axial code identified in favor of a cooperative approach is reputation. The interviews have highlighted how, in Omega, the historicity of the leader who attracts new network members is positively recognized $[10,11]$. Further, the mere fact of participating in the network creates a positive influence on the reputation of the network operators, who are comfortable in exchanging knowledge and instrumentation [8].

The second selective code identified in the research is the role of the business network in supporting environmental sustainability, a topic relevant to research as many commons characterize the empirical setting's environment. According to the literature, the safeguarding and development of common goods allow a double benefit: economic and social. This aspect finds support in the Omega case, where a social entrepreneur can be recognized in the figure of the network leader who cares not only about his or her interests, but also about the community and the environment by prohibiting, for example, the use of herbicides and chemical products. The leader also tends to encourage, at the same time, the implementation of natural techniques, resulting in consistent positive externalities for the environment and the community [17].

Economic and social sustainability are both dealt with by implementing experiments that allow for achievement of good profit margins at the same time as protecting the environment [18], while considering the collective achievement of objectives [19]. The social entrepreneur in Omega supports respect for the environment and the common goods using nonintensive practices and thus guarantees a high-quality product that is certified. The certification chosen by the network is not limited to confirming the quality of the product but also addresses a whole spectrum of factors. Examples include good business practices, respect for the environment, and the analysis of environmental indicators, thus certifying the 360-degree network. The motivations that push Omega to work toward a product that respects the land and the environment are not tied to profit but to an underlying ethic that guides the work of the leader toward sustainability. This ethic is transmitted by the leader to all the participants in the network, thus creating a powerful nested institution in which transparency allows the effective management of environmental uncertainty [17].

The third selective code is adaptive co-management, which is management that adapts to changes in the external environment and allows for the co-creation of adaptive knowledge [24]. Omega supports the continuous experimentation in sustainability by dedicating specific areas for research. In this way, it confirms the need for a strongly experimental attitude of decision-makers, as stated in the literature [18]. The literature highlights the importance of the role of a "bridge organization" that facilitates constructive interaction between the main stakeholders of common goods. This "bridge organization" must integrate knowledge, control common assets and their fragility, and encourage participative decisions by imposing rules. In Omega, this role is held by technicians who work side by side with network members and are always available, facilitating communication between network participants and the leader [28] while ensuring greater transparency [17]. 
In this way, the decision-making process in Omega can be considered the engine of a continuous and adaptive process. The literature argues that the involvement of the local community and the main stakeholders is indispensable for the success of adaptive management [23]. Adaptive co-management systems are flexible systems that enable learning [26]. Adaptive co-management can be defined as a process through which institutional schemes and ecological knowledge are tested and reviewed in a dynamic, continuous, and self-organized learning process [27]. The last theme identified in Omega in support of adaptive co-management is that of entrepreneurial learning. In the network, there is a great openness to listening to new ideas and techniques. The network leader invites the participants to share their knowledge because this can benefit the group which, in the face of what has been learned, can modify its management and develop best practices [24].

This last topic analyzed also supports a fourth selective code: learning as participation. According to the literature, knowledge is the result of a dynamic process in which a subject actively participates in a context in which numerous topics interact.

The sharing of knowledge within the group also allows small businesses, such as network members, to benefit from a pool of high-quality information [29]. Further, in Omega, theoretical and practical training courses are organized during which technicians and network participants work side by side, sharing their knowledge and experience. This encouragement of sharing allows for learning together [29].

The four selective codes identified in the research confirm the existence in the chosen empirical setting of a positive relationship between the network organization and commons; therefore, the chosen case study addresses the selected research question.

\section{Conclusions}

The study examined the role played by the network organizational form in the implementation, development, and protection of the commons in the agricultural industry. In the Omega case study, four selective codes were identified that confirm the positive relationship between the organizational form of the business network and the commons. The first selective code highlights the importance of the cooperative approach and trust; the study showed that trust appears to be a necessary ingredient for starting relationships between subjects, and it makes cooperation possible. The homogeneity of the participants allows for the creation of a cohesive group, one that is characterized by the same values and works toward the same goal. Trust and cooperation are abstract common assets that develop within a business network as a result of collaboration, the sharing of skills and knowledge, and reputation.

The second selective code emphasizes the importance of working within the network to support sustainability. The presence in Omega of a social entrepreneur who cares not only for the economic well-being of the network but also for social welfare, and therefore for the community and the reference environment, underlines how the common goods are protected. This is confirmed by the practices employed in the network in all the phases of the production process. Some examples of these practices are the abolition of herbicides, the limitation in the use of chemical products, and use of manual methods of harvesting. All this is possible in Omega, thanks to the ethics underlying the creation of the network that encourages all participants to work in a sustainable way.

The third and fourth selective codes focus on co-adaptive management and learning as participation. The co-adaptive management in Omega allows network participants to keep up with changes in the external environment and, above all, to create adaptive knowledge in a sharing logic. Omega attaches great importance to continuous experimentation and shares the results with all members of the network, thus enabling a constant and dynamic decision-making process. In the network, there is a great openness to listening, and technicians act as a bridge between the leader and the participants in the network. This feature guarantees transparency and the development of best practices, which often come from the smaller firms inside the network. The sharing of knowledge and skills usually takes place in the field, working side by side, learning through participation and sharing of experiences and 
knowledge. In Omega, new knowledge and practices are developed, pushing the network toward greater sustainability.

The Omega case highlights how the business network can be considered a useful organizational form for protecting and employing common goods in sustainable ways. The network also becomes a tool that allows the development of commons, as a result of collaboration, communication, and the sharing of knowledge, skills, and equipment. All these aspects can generate strategic value for a networked organization, which can derive significant benefit from both the common goods developed and the organizational form implemented. At the same time, these aspects can create social and environmental value as a result of the protection of the environment and implementation of sustainable practices, generating strong positive externalities for the organization and the community.

Author Contributions: Conceptualization L.B.O., E.D.M., C.R., and S.B.; Data curation, E.D.M.; Formal analysis, E.D.M.; Methodology, L.B.O.; Supervision, C.R.; Writing-original draft, L.B.O., E.D.M., C.R., and S.B.; Writing-review \& editing, C.R. and S.B.

Funding: This research received no external funding

Conflicts of Interest: The authors declare no conflict of interest.

\section{Appendix A. Examples of Coding}

\begin{tabular}{|c|c|c|c|c|}
\hline Source. & Quote & Open Coding & Axial Coding & $\begin{array}{l}\text { Selective } \\
\text { Coding }\end{array}$ \\
\hline $\begin{array}{c}\text { Network } \\
\text { Leader }\end{array}$ & $\begin{array}{l}\text { "If you have something to } \\
\text { share: experiences and } \\
\text { knowledge, bring them; we } \\
\text { are not the best, we try to } \\
\text { document and improve } \\
\text { ourselves, and there can } \\
\text { always be someone smarter, } \\
\text { better documented than us } \\
\text { who can bring culture into } \\
\text { the network, and all this can } \\
\text { also come from the small } \\
\text { farmer who put one hectare } \\
\text { on the network, not only } \\
\text { from the big one." }\end{array}$ & $\begin{array}{c}\text { Openness to } \\
\text { collaboration and } \\
\text { cooperation to } \\
\text { promote } \\
\text { knowledge sharing } \\
\text { among network } \\
\text { participants }\end{array}$ & $\begin{array}{c}\text { Trust in } \\
\text { information } \\
\text { Entrepreneurial } \\
\text { learning }\end{array}$ & $\begin{array}{c}\text { Cooperative } \\
\text { approach: } \\
\text { development of } \\
\text { trust } \\
\text { Learning as } \\
\text { participation }\end{array}$ \\
\hline $\begin{array}{l}\text { Network } \\
\text { Leader }\end{array}$ & $\begin{array}{l}\text { "We are all farmers, } \\
\text { therefore sharing the } \\
\text { objective is essential, and } \\
\text { geographical proximity } \\
\text { allows interventions on the } \\
\text { territory to work side by } \\
\text { side and therefore to transfer } \\
\text { knowledge." }\end{array}$ & $\begin{array}{l}\text { The similarity } \\
\text { between network } \\
\text { participants in } \\
\text { terms of activity, } \\
\text { area, and objectives } \\
\text { facilitates } \\
\text { cooperation }\end{array}$ & Homophily & $\begin{array}{c}\text { Cooperative } \\
\text { approach: } \\
\text { development of } \\
\text { trust }\end{array}$ \\
\hline $\begin{array}{l}\text { Network } \\
\text { Manager }\end{array}$ & $\begin{array}{l}\text { “To build a relationship } \\
\text { based on trust, during the } \\
\text { whole winter I personally } \\
\text { meet people of other } \\
\text { network companies, and I } \\
\text { share my specialization, } \\
\text { during this long period in } \\
\text { which we work together we } \\
\text { create a strong bond, we } \\
\text { create trust." }\end{array}$ & $\begin{array}{l}\text { Trust is built as a } \\
\text { result of the direct } \\
\text { relationship } \\
\text { between network } \\
\text { participants }\end{array}$ & Trust building & $\begin{array}{c}\text { Cooperative } \\
\text { approach: } \\
\text { development of } \\
\text { trust }\end{array}$ \\
\hline
\end{tabular}




\begin{tabular}{|c|c|c|c|c|}
\hline Source. & Quote & Open Coding & Axial Coding & $\begin{array}{l}\text { Selective } \\
\text { Coding }\end{array}$ \\
\hline $\begin{array}{l}\text { Network } \\
\text { Leader }\end{array}$ & $\begin{array}{l}\text { "We try to do our utmost to } \\
\text { have a double benefit from the } \\
\text { actions we put in place: social } \\
\text { sustainability and economic } \\
\text { sustainability." }\end{array}$ & $\begin{array}{l}\text { Orientation toward } \\
\text { both economic and } \\
\text { social sustainability }\end{array}$ & $\begin{array}{c}\text { Social } \\
\text { entrepreneur }\end{array}$ & $\begin{array}{l}\text { Network in } \\
\text { support of } \\
\text { sustainability }\end{array}$ \\
\hline $\begin{array}{c}\text { Gamma } \\
\text { Entrepreneur }\end{array}$ & $\begin{array}{l}\text { "I'm always in touch with the } \\
\text { two technicians, but the good } \\
\text { thing is that even the network } \\
\text { leader is available and I feel in } \\
\text { a position to contact him } \\
\text { without problems." }\end{array}$ & $\begin{array}{l}\text { Technicians act as a } \\
\text { bridge between the } \\
\text { leading company } \\
\text { and the network, } \\
\text { providing } \\
\text { transparent } \\
\text { communication }\end{array}$ & $\begin{array}{c}\text { Bridge } \\
\text { organization }\end{array}$ & $\begin{array}{l}\text { Network in } \\
\text { support of } \\
\text { sustainability } \\
\text { Adaptive } \\
\text { co-management }\end{array}$ \\
\hline $\begin{array}{c}\text { Gamma } \\
\text { Entrepreneur }\end{array}$ & $\begin{array}{l}\text { "Given the quality, history, } \\
\text { experience, and knowledge of } \\
\text { the leader company of the } \\
\text { network all the participants } \\
\text { are pleased to join the } \\
\text { network, it would be } \\
\text { expensive to do all the studies } \\
\text { that they have already done." }\end{array}$ & $\begin{array}{l}\text { The experience and } \\
\text { historicity of the } \\
\text { leading company } \\
\text { are recognized; its } \\
\text { reputation } \\
\text { encourages } \\
\text { participation in the } \\
\text { network }\end{array}$ & Reputation & $\begin{array}{l}\text { Cooperative } \\
\text { approach: } \\
\text { development of } \\
\text { trust }\end{array}$ \\
\hline $\begin{array}{l}\text { Network } \\
\text { Leader }\end{array}$ & $\begin{array}{l}\text { "If you have something to } \\
\text { share: experiences and } \\
\text { knowledge bring them, we are } \\
\text { not the best, we try to } \\
\text { document and improve } \\
\text { ourselves, and there can } \\
\text { always be someone smarter, } \\
\text { better documented than us } \\
\text { who can bring culture into the } \\
\text { network, and all this can also } \\
\text { come from the small farmer } \\
\text { who put one hectare on the } \\
\text { network, not only from the } \\
\text { big one." }\end{array}$ & $\begin{array}{l}\text { Knowledge sharing } \\
\text { could modify the } \\
\text { overall } \\
\text { management and } \\
\text { enhance new best } \\
\text { practice } \\
\text { development }\end{array}$ & $\begin{array}{c}\text { Entrepreneurial } \\
\text { learning }\end{array}$ & $\begin{array}{c}\text { Adaptive } \\
\text { co-management } \\
\text { Learning as } \\
\text { participation }\end{array}$ \\
\hline $\begin{array}{l}\text { Network } \\
\text { Leader }\end{array}$ & $\begin{array}{l}\text { "We do the plan, but we are } \\
\text { open to the ideas from the } \\
\text { network because, thanks to } \\
\text { listening, we are able } \\
\text { to innovate." }\end{array}$ & $\begin{array}{l}\text { Openness to } \\
\text { listening to new } \\
\text { ideas and } \\
\text { techniques }\end{array}$ & $\begin{array}{c}\text { Entrepreneurial } \\
\text { learning }\end{array}$ & $\begin{array}{c}\text { Adaptive } \\
\text { co-management } \\
\text { Learning as } \\
\text { participation }\end{array}$ \\
\hline $\begin{array}{c}\text { Beta } \\
\text { Entrepreneur }\end{array}$ & $\begin{array}{l}\text { "The other network operators } \\
\text { are noncompeting } \\
\text { collaborators, very often we } \\
\text { exchanged machinery, which } \\
\text { without the network would } \\
\text { not have been possible } \\
\text { because I would not have } \\
\text { known them, and I would not } \\
\text { have created the confidence } \\
\text { that there is." }\end{array}$ & $\begin{array}{l}\text { Great collaboration } \\
\text { among network } \\
\text { participants thanks } \\
\text { to the trust } \\
\text { established; they } \\
\text { met each other on } \\
\text { the network, and } \\
\text { they recognized in } \\
\text { each other their } \\
\text { shared values and } \\
\text { objectives }\end{array}$ & Reputation & $\begin{array}{c}\text { Cooperative } \\
\text { approach: } \\
\text { development of } \\
\text { trust }\end{array}$ \\
\hline
\end{tabular}




\begin{tabular}{|c|c|c|c|c|}
\hline Source. & Quote & Open Coding & Axial Coding & $\begin{array}{l}\text { Selective } \\
\text { Coding }\end{array}$ \\
\hline $\begin{array}{c}\text { Alfa } \\
\text { Entrepreneur }\end{array}$ & $\begin{array}{l}\text { "The network leader } \\
\text { practices give the chance to } \\
\text { create a standard, to develop } \\
\text { economies of scale and } \\
\text { experiences, common } \\
\text { knowledge without it a } \\
\text { single company would have } \\
\text { to spend a great deal to } \\
\text { obtain both in economic } \\
\text { terms and in terms of time." }\end{array}$ & $\begin{array}{l}\text { The reputation and } \\
\text { experience of the } \\
\text { leading company } \\
\text { are very important } \\
\text { for promoting } \\
\text { participation in the } \\
\text { network }\end{array}$ & Reputation & $\begin{array}{c}\text { Cooperative } \\
\text { approach: } \\
\text { development of } \\
\text { trust }\end{array}$ \\
\hline $\begin{array}{c}\text { Alfa } \\
\text { Entrepreneur }\end{array}$ & $\begin{array}{l}\text { "If I want to get a quality } \\
\text { product, being a fruit of the } \\
\text { earth, the importance of } \\
\text { respecting the land and the } \\
\text { environment cannot be left } \\
\text { in the background. I believe } \\
\text { in the use of certain types of } \\
\text { noninvasive processes with } \\
\text { an eye towards the } \\
\text { environment and } \\
\text { the territory." }\end{array}$ & $\begin{array}{l}\text { The network } \\
\text { considers the } \\
\text { protection of the } \\
\text { environment to be } \\
\text { critical }\end{array}$ & $\begin{array}{l}\text { Respect for the } \\
\text { environment }\end{array}$ & $\begin{array}{l}\text { Network in } \\
\text { support of } \\
\text { sustainability }\end{array}$ \\
\hline $\begin{array}{l}\text { Beta } \\
\text { Entrepreneur }\end{array}$ & $\begin{array}{l}\text { "The network is very } \\
\text { focused on environmental } \\
\text { and territorial sustainability } \\
\text { and has proposed } \\
\text { environmental certifications } \\
\text { to the network operators. I } \\
\text { did the Biodiversity Friends } \\
\text { that certify that my } \\
\text { production is sustainable." }\end{array}$ & $\begin{array}{l}\text { A key point of the } \\
\text { network is } \\
\text { environmental } \\
\text { sustainability, and } \\
\text { for this reason, it } \\
\text { invites network } \\
\text { participants to } \\
\text { comply with } \\
\text { indicators to obtain } \\
\text { certification }\end{array}$ & $\begin{array}{l}\text { Certified } \\
\text { quality }\end{array}$ & $\begin{array}{l}\text { Network in } \\
\text { support of } \\
\text { sustainability }\end{array}$ \\
\hline $\begin{array}{c}\text { Gamma } \\
\text { Entrepreneur }\end{array}$ & $\begin{array}{l}\text { "The creation of this } \\
\text { network is also based on } \\
\text { environmental sustainability; } \\
\text { it is a pillar of the network. } \\
\text { A quality product with } \\
\text { environmental attention and } \\
\text { sustainability. This network } \\
\text { has a vision towards the } \\
\text { future, driving the world of } \\
\text { viticulture, introducing } \\
\text { innovation, and new topics } \\
\text { such as sustainability, } \\
\text { attention to the land, } \\
\text { and landscape." }\end{array}$ & $\begin{array}{l}\text { The network wants } \\
\text { to offer a quality } \\
\text { product that } \\
\text { respects, protects, } \\
\text { and safeguards the } \\
\text { environment }\end{array}$ & $\begin{array}{l}\text { Respect for the } \\
\text { environment }\end{array}$ & $\begin{array}{l}\text { Network in } \\
\text { support of } \\
\text { sustainability }\end{array}$ \\
\hline
\end{tabular}




\begin{tabular}{|c|c|c|c|c|}
\hline Source. & Quote & Open Coding & Axial Coding & $\begin{array}{l}\text { Selective } \\
\text { Coding }\end{array}$ \\
\hline $\begin{array}{c}\text { Gamma } \\
\text { Entrepreneur }\end{array}$ & $\begin{array}{l}\text { "Here there is no effort to do } \\
\text { it because we have to, but } \\
\text { only because we like doing it. } \\
\text { Therefore, it is not produced } \\
\text { this way only because the } \\
\text { market requires it or because } \\
\text { doing so we can earn more, } \\
\text { or because everyone does it, } \\
\text { but because it is heard from } \\
\text { within because for ethical } \\
\text { and ecological reasons we } \\
\text { feel it is right." }\end{array}$ & $\begin{array}{l}\text { The choice of being } \\
\text { oriented toward } \\
\text { sustainability is not } \\
\text { economic but } \\
\text { ethical }\end{array}$ & $\begin{array}{c}\text { Ethical } \\
\text { motivation }\end{array}$ & $\begin{array}{l}\text { Network in } \\
\text { support of } \\
\text { sustainability }\end{array}$ \\
\hline $\begin{array}{c}\text { Gamma } \\
\text { Entrepreneur }\end{array}$ & $\begin{array}{l}\text { "We are looking for } \\
\text { something new that can be } \\
\text { useful in a broad sense, for } \\
\text { collective well-being and not } \\
\text { just for economic } \\
\text { well-being." }\end{array}$ & $\begin{array}{l}\text { Orientation to } \\
\text { collective } \\
\text { well-being }\end{array}$ & $\begin{array}{c}\text { Social } \\
\text { entrepreneur }\end{array}$ & $\begin{array}{l}\text { Network in } \\
\text { support of } \\
\text { sustainability }\end{array}$ \\
\hline $\begin{array}{l}\text { Network } \\
\text { Manager }\end{array}$ & $\begin{array}{l}\text { "Trust in this group is the } \\
\text { result of daily work, } \\
\text { working side by side, and } \\
\text { sharing experiences and } \\
\text { knowledge." }\end{array}$ & $\begin{array}{c}\text { Technicians and } \\
\text { network operators } \\
\text { work side by side, } \\
\text { sharing their } \\
\text { knowledge }\end{array}$ & $\begin{array}{l}\text { Learning } \\
\text { together }\end{array}$ & $\begin{array}{l}\text { Learning as } \\
\text { participation }\end{array}$ \\
\hline $\begin{array}{l}\text { Network } \\
\text { Manager }\end{array}$ & $\begin{array}{l}\text { "For what concerns research } \\
\text { field, Omega research are } \\
\text { experimented and tested in } \\
\text { the field to protect the vine } \\
\text { and replace the } \\
\text { old-generation products } \\
\text { with the most innovative } \\
\text { ones and reduce their } \\
\text { number, after appropriate } \\
\text { experiments, which is why } \\
\text { they dedicate several } \\
\text { hectares to } \\
\text { experimentation." }\end{array}$ & $\begin{array}{l}\text { Continuous } \\
\text { experimentation } \\
\text { and evaluation of } \\
\text { innovative } \\
\text { practices }\end{array}$ & $\begin{array}{l}\text { Experimentation } \\
\text { and evaluation }\end{array}$ & $\begin{array}{c}\text { Adaptive } \\
\text { co-management }\end{array}$ \\
\hline $\begin{array}{l}\text { Network } \\
\text { Leader }\end{array}$ & $\begin{array}{l}\text { "Certification is the basis of } \\
\text { the network project, and } \\
\text { consequently, all network } \\
\text { operators must strive to } \\
\text { meet quality indicators. The } \\
\text { certification then falls on the } \\
\text { product, the wine, and since } \\
\text { this is the fruit of the grapes } \\
\text { of all the networkers, all } \\
\text { must respect the same } \\
\text { standard to obtain the } \\
\text { certification." }\end{array}$ & $\begin{array}{l}\text { Network } \\
\text { environmental } \\
\text { certifications are } \\
\text { central because } \\
\text { they confirm the } \\
\text { quality of the } \\
\text { product and the } \\
\text { implementation of } \\
\text { agricultural } \\
\text { practices oriented } \\
\text { toward } \\
\text { sustainability }\end{array}$ & $\begin{array}{l}\text { Certified } \\
\text { quality }\end{array}$ & $\begin{array}{c}\text { Network in } \\
\text { support of } \\
\text { sustainability }\end{array}$ \\
\hline
\end{tabular}




\section{References}

1. Commission Regulation (EC) No 800/2008. Declaring certain categories of aid compatible with the common market in application of Articles 87 and 88 of the Treaty (General Block Exemption Regulation), European Commission. Available online: https://eur-lex.europa.eu/legal-content/EN/TXT/?uri=CELEX\% 3A32008R0800 (accessed on 6 August 2008).

2. Centro Studi Confagricoltura. Reti D'impresa; Confagricoltura. Available online: http: //www.confagricoltura.it/ita/comunicazioni_centro-studi/rapporti-economici/nel-2018-reti-di-imprese-19imprese-in-reti-34-imprese-agricole-in-reti-di-imprese-52.php (accessed on 6 August 2008).

3. Bravo, G. Dai pascoli a internet. La teoria delle risorse comuni. Stato Mercato 2001, 63, 487-492.

4. Hess, C. Mapping the New Commons. Available online: https://ssrn.com/abstract=1356835 (accessed on 1 July 2008).

5. Bonomi, S.; Rossignoli, C.; Ricciardi, F. The emergence of adaptive management as a key success factor in science \& technology parks: An Italian case. In Proceedings of the 11th International Forum of Knowledge Asset Dynamics, Towards a New Architecture of Knowledge: Big Data, Culture and Creativity, Dresden, Germany, 16 June 2016.

6. Moridi, A.; Tabatabaie, M.R.M.; Esmaeelzade, S. Holistic approach to sustainable groundwater management in semi-arid regions. Int. J. Environ. Res. 2018, 12, 347-355. [CrossRef]

7. Olson, M. The Logic of Collective Action: Public Goods and the Theory of Groups; Harvard University Press: Cambridge, MA, USA, 1965.

8. Henry, A.D.; Dietz, T. Information, networks, and the complexity of trust in commons governance. Int. J. Commons 2011, 5, 188-212. [CrossRef]

9. Josang, A.; Gray, E.; Kinateder, M. Simplification and analysis of transitive trust networks. Web Intell. Agent Syst. 2006, 4, 139-161.

10. Ostrom, E.; Gardner, R.; Walker, J. Rules, Games, E Common-Pool Resources; The University of Michigan Press: Ann Arbor, MI, USA, 1994.

11. Fehr, E.; Gächter, S. Fairness and retaliation: The economics of reciprocity. J. Econ. Perspect. 2000, 14, $159-181$. [CrossRef]

12. McPherson, M.; Smith-Lovin, L.; Cook, J.M. Birds of a feather: Homophily in social networks. Ann. Rev. Soc. 2001, 27, 415-444. [CrossRef]

13. Meyer, R.C.; Davis, J.H.; Schoorman, F.D. An integrative model of organizational trust. Acad. Manag. Rev. 1995, 20, 709-734. [CrossRef]

14. Wuyts, S.I. The formation of buyer-supplier relationships: Detailed contract drafting and close partner selection. J. Mark. 2005, 69, 103-117. [CrossRef]

15. Muthusamy, S.K.; White, M.A.; Carr, A. An empirical examination of the role of social exchanges in alliance performance. J. Manag. Issues 2007, 19, 53-75.

16. Vittikh, V.A. Introduction to the theory of intersubjective management. Group Decis. Negot. 2015, $24,67-95$. [CrossRef]

17. Rossignoli, C.; Ricciardi, F.; Bonomi, S. Organizing for commons-enabling decision-making under conflicting institutional logics in social entrepreneurship. Group Decis. Negot. 2018, 27, 417-443. [CrossRef]

18. Cantino, V.; Devalle, A.; Cortese, D.; Ricciardi, F.; Longo, M. Place-based network organizations and embedded entrepreneurial learning: Emerging paths to sustainability. Int. J. Entrep. Behav. Res. 2017, 23, 504-523. [CrossRef]

19. Giest, S.; Howlett, M. Understanding the pre-conditions of commons governance: The role of network management. Environ. Sci. Policy 2014, 36, 37-47. [CrossRef]

20. Walker, B.; Holling, C.S.; Carpenter, S.R.; Kinzig, A. Resilience, adaptability and transformability in social-ecological systems. Ecol. Soc. 2004, 9, 5. [CrossRef]

21. Brunner, R.D.; Steelman, T.A.; Coe-Juell, L.; Crowley, C.M.; Edwards, C.M.; Tucker, D.W. Adaptive Governance: Integrating Science, Policy, and Decision Making; Columbia University Press: New York, NY, USA, 2005.

22. Berkes, F.; Folke, C.; Colding, J. (Eds.) Linking Social and Ecological Systems: Management Practices and Social Mechanisms for Building Resilience; Cambridge University Press: Cambridge, UK, 2000. 
23. Armitage, D.R.; Plummer, R.; Berkes, F.; Arthur, R.I.; Charles, A.T.; Davidson-Hunt, I.J.; Diduck, A.P.; Doubleday, N.C.; Johnson, D.S.; Marschke, M.; et al. Adaptive co-management for social-ecological complexity. Front. Ecol. Environ. 2008, 7, 95-102. [CrossRef]

24. Wyborn, C. Co-productive governance: A relational framework for adaptive governance. Glob. Environ. Chang. 2015, 30, 56-67. [CrossRef]

25. Schuttenberg, H.Z.; Guth, H.K. Seeking our shared wisdom: A framework for understanding knowledge coproduction and coproductive capacities. Ecol. Soc. 2015, 20, 15. [CrossRef]

26. Dietz, T.; Ostrom, E.; Stern, P.C. The struggle to govern the commons. Science 2003, 302, 1907-1912. [CrossRef]

27. Folke, C.; Hahn, T.; Olsson, P.; Norberg, J. Adaptive governance of social-ecological systems. Ann. Rev. Environ. Res. 2005, 30, 441-473. [CrossRef]

28. Crona, B.; Parker, J. Learning in support of governance: Theories, methods, and a framework to assess how bridging organizations contribute to adaptive resource governance. Ecol. Soc. 2012, 17, 32. [CrossRef]

29. Eisenhardt, K.M.; Graebner, M.E.; Sonenshein, S. Grand challenges and inductive methods: Rigor without rigor mortis. Acad. Manag. J. 2016, 59, 1113-1123. [CrossRef]

30. Stake, R.E. Multiple Case Study Analysis; Guilford Press: New York, NY, USA, 2013.

31. Bryman, A.; Bell, E. Business Research Methods; Oxford University Press: Oxford, UK, 2011.

32. Denzin, N.K. The Research Act: A Theoretical Introduction to Sociological Methods; McGraw-Hill: New York, NY, USA, 1978.

33. Heyl, B.S. Ethnographic interviewing. In Handbook of Ethnography; Atkinson, P., Coffey, A., Delamont, S., Lofland, J., Lofland, L., Eds.; Sage: London, UK, 2001; pp. 369-379.

34. Miles, M.B.; Huberman, A.M.; Saldaña, J. Qualitative Data Analysis: A Methods Sourcebook; Sage: London, UK, 2014.

(C) 2019 by the authors. Licensee MDPI, Basel, Switzerland. This article is an open access article distributed under the terms and conditions of the Creative Commons Attribution (CC BY) license (http://creativecommons.org/licenses/by/4.0/). 